\title{
An Aristotelian-Communitarian Reading of South Korea's Saemaul Undong and South Korean Society: Originarity \& the Importance of Language vis-à-vis Sub-Saharan Africa and South Africa
}

\author{
Casper Hendrik Claassen \\ Department of Political Sciences, University of Pretoria, 0002, Pretoria \\ E-mail: casper.claassen@up.ac.za
}

Received: November 27, $2010 \quad$ Accepted: February 12, $2011 \quad$ doi:10.5539/ass.v7n7p124

\begin{abstract}
In this essay it is posited that an Aristotelian reading of Saemaul Undong - a hugely successful South Korean rural development scheme implemented in the 1970 s which led to the near eradication of rural poverty - can provide an understanding of the dynamics that were involved in this scheme and how these dynamics allowed for the transformation of feelings of hopelessness and indifference within the rural population of South Korea into feelings which were conducive to rural development. It is argued that Saemaul Undong can be, to some extent, equated with the Polis (city-state) as understood by Aristotle and through this equation the character-building as well as community-building properties of Saemaul Undong can be understood. It is argued that sub-Saharan Africa could potentially benefit from the adoption of something akin to Saemaul Undong, both in the micro sense of the transformation of both individual and communal feelings and the capacity for the construction of a collective identity (vital in a largely heterogeneous region) inherent within Saemaul Undong, as well as the skills acquired by those involved through participation in this process, and in the macro sense of the eradication of rural poverty. From this foundation an attempt will be made to incorporate the notion of Originarity, as formulated by Leopold Peeters, as well as the notion that humans externalise their existence by means of language. Moreover, South Korean society and cinema will also be investigated within the context of the aforementioned.
\end{abstract}

Keywords: Saemaul Undong, Peeters, Language, South Korea, South Africa, Communitarianism, Aristotle, Virtue ethics

\section{Introduction}

Rural poverty - which will be taken to refer to the general impoverishment of black Africans, be it in rural areas or informal settlements, such as those on the outskirts of cities - has persisted as an affliction faced by the majority of countries in sub-Saharan Africa (SSA) (Rodik, 1996:13), with rural poverty acting as a weight that has hampered the development effort of most of SSA. Rural poverty has invariably led to the proliferation of feelings such as hopelessness and indifference among those affected by it, which has often been accompanied by a Weltanschauung which is not conducive to development by virtue of it being characterised by vices such as greed, lack of communal and social responsibility, and indifference to the feelings of others - as manifested by widespread corruption. Development models such as the Institutional Reform Model, the Constitutional Politics Model, the Power-Sharing Model, and the State Deconstruction Model (Agabese \& Keih, 2007:14-19) have all failed to deliver SSA from rural poverty due to their disregard for the feelings, or emotions, and attitudes of the populace. Stated succinctly, rural poverty has been an affliction that has been the chief bane of most of SSA. A number of social ills within SSA, arguably, stem from it.

Before attempting an analysis, it is necessary to understand how South Korea eradicated rural poverty. Countries such as South Korea, Taiwan, and Japan managed to free themselves from rural poverty despite being on relatively equal terms with SSA in the 1950's. South Korea did so, despite the devastation of the Korean War, through the adoption of rural village programmes (Park, 2009:113). South Korea initiated Saemaul Undong (Note 1) (새마을 운동) in the 1970s (Douglass, 1983:189) while a similar idea, the 'One Village, One Product' Movement, has been conceived of in Japan (Knight, 1994:638). South Korea's Saemaul Undong was particularly successful considering the context within which it occurred. Before the initiation of Saemaul Undong by the Park Chung-hee regime South Korea, in the 1950s and 1960s, was ravaged by rural poverty. Since the majority of the national population at the time was based in farming houses, the effect of rural poverty was huge (Ho, 1979:646). 
The inequality between urban and rural areas caused by rural poverty led to the possibility of urban areas becoming increasingly unstable as much of the rural population swarmed to urban areas (Ho, 1979: 646). Natural resources could not deliver South Korea from rural poverty, since the country is not abundant in natural resources, and neither could the government of the time (Ho, 1979:647), since South Korea was a relatively destitute country and foreign aid was sufficient (Lockwood, 2005). Due to the high rate of rural poverty, the rural population suffered from feelings such as hopelessness and indifference. South Korea could only free itself from rural poverty through the awakening and participation of its population, specifically the rural population. The government of the time, led by Park Chung-hee, realised this, and subsequently initiated Saemaul Undong, with the hope of inspiring the rural population and thereby facilitating self-sustained progress within rural communities (Lee, 1990:3). To highlight the success of Saemaul Undong, consider the statistics illustrated in Tables 1, 2, 3, and 4 (Park, 2009:118-119).

\section{[approximate location of Tables 1-4]}

\section{An Aristotelian-Communitarian Reading of Saemaul Undong}

Saemaul Undong emphasised values such as diligence, which it contended would lead to sincerity and the awakening of a pioneer spirit, or the awakening of a strong will; self-help, which it held would awaken a sense of responsibility, and communal and social responsibility by extension; and, cooperation, which it posited would lead to dispositions toward unity and efficiency being awakened (Park, 2009:5).' The primary objectives were the building of infrastructure, spiritual enlightenment and social interaction, the improvement of living standards and increased income (Park, 2009:8).

The Park Chung-hee regime divided the project into three phases. The first phase involved giving simple projects to villages, a village chief being nominated and projects being pushed through general meetings of villagers. Distribution to individual households was banned - resources were communally owned. Essentially, villages were provided with various incentives to succeed, both communal and individual. Villages that performed well in the first phase were rewarded with progressively more ambitious projects and greater resources. Government inspectors regularly visited villages in order to monitor progress. Projects were primarily divided into environmental, income increasing, productivity enhancement and cultural projects. Factories, schools, libraries, and various community facilities were constructed. As villages advanced, inter-village cooperation became necessary. By the conclusion of the project, rural poverty was almost completely eradicated, with the vast majority of villages moving from dependent to semi-dependent to virtually autonomous, or self-help, villages (Park, 2009:4-6). (Note 2) (Note 3)

During the Saemaul Undong programme the South Korean government assisted rural villages in development efforts by appointing a village leader, giving limited supplies and aid - both material and technical - and by doing regular investigation of progress at villages. The South Korean government, furthermore, provided huge incentives for the village leader and the villagers to perform well. Moreover, if a village was not making progress, aid would simply be cut. Rural poverty was subsequently eradicated in South Korea with rapid development occurring throughout. Importantly, this might be explained as being possible due to the relative homogenous societies of these countries as well as their deeply-embedded cultures of education and learning. However, these factors are not the only factors to consider and can be potentially bypassed.

To understand why Saemaul Undong was so successful, an Aristotelian reading of it might be proposed. The logic of the transformative process of Saemaul Undong can perhaps be best understood via the adoption of an Aristotelian vocabulary, as read by pre-eminent political philosopher Michael Oakeshott (2006: 120-124), particularly Aristotle's virtue ethics, teleology and understanding of the Polis. The adoption of an Aristotelian vocabulary can allow for an understanding of how Saemaul Undong managed to transform those who participated. It is recognised, however, that not all aspects of Aristotle's ethics and politics will conform to the logic of the transformative process of Saemaul Undong, with the emphasis rather being placed on specific aspects of Aristotle's ethics and politics.

Aristotle's virtue ethics is essentially concerned with the cultivation of character. Aristotle argued that there are certain excellences, or virtues (Arête) which pertain to the practice of being a human. Aristotle argued that humans, like all other things that constitute the Cosmos, have a certain potentiality and that in order to fulfil this potentiality humans need to achieve Eudaimonia - the state of having reached a type of non-subjective, non-pleasure-based happiness defined by moral, prudential, and intellectual excellence and other virtues, such as moral courage - which requires habituation. Aristotle argued that the virtuous character, the character which has achieved Eudaimonia, is defined by attitudes such as empathy and compassion, forgiveness and understanding, temperance and moderation, self-respect and remorse - and all other attitudes and emotions associated with the 
Golden Mean. It is important to note that Aristotle's notion of potentiality is based on freedom and participation in the Agora life, which implies that only those who are free can achieve Eudaimonia, and through this achievement they conform to the Aristotelian notion of Megalopsychos, or the 'great-souled man', the archetype of goodness and virtue (Oakeshott, 2006:120-124).

Aristotle furthermore held that, like humans, the Polis has an intrinsic potentiality and the ability of humans to fulfil their own potentiality directly correlates to the achievement of the potentiality of the Polis. This depends on the degree of the achievement of justice (Dike). This achievement is dependent on a life centred on the Agora and the spirit which it encapsulates (that of deliberation) which implies an effort to facilitate mutual understanding and the advancement of mutual understanding such as in the Gadamerian dialectic. Notably, Aristotle's Polis plays a significant role in combating Akrasia (or the weakness of will) among the population and, instead, fosters temperance or self-mastery (Oakeshott, 2006: 106-110), - this belief runs contrary to the notion held by Plato that Akrasia cannot exist (Dupre, 2007:98-99).

Saemaul Undong can be understood as being a reflection of the emphasis that Aristotle placed on the Polis and the potential of the Polis to instil a virtuous character in its members. The villages that were involved in Saemaul Undong acted in a very similar way to the way in which the Polis, as envisioned by Aristotle, acted in instilling a virtuous character within the rural population, primarily through the transformation of the attitudes and emotions of the rural population. Saemaul Undong inserted emotions and attitudes such as hope, courage, diligence, compassion and camaraderie and feelings of communal, and social, responsibility within the rural population. Through participation in communal activities - something which was emphasised - and the existence of something akin to the Agora in the sense of the general meeting hall, general meetings and communal facilities, the villagers of successful villages could develop towards Eudaimonia in developing the following, as described by Furnham (2008:54-55), courage and values which act as the conditions for courage, such as persistence, integrity, vitality and bravery; wisdom and knowledge and, by extension, creativity, curiosity, open-mindedness, love or learning and perspective; humanity, which is characterised by love, kindness and social intelligence; temperance, which leads to notions such as forgiveness and mercy, humility and modesty, prudence and self-regulation; transcendence and an appreciation of beauty and excellence, gratitude, hope, humour and spirituality; and, finally, a sense of justice, and via this an understanding of fairness and what citizenship means and requires, such as active participation, and the qualities of good leadership.

Villages, moreover, played an important role in combating Akrasia, the majority of villagers understood what kind of life they should live even before the introduction of Saemaul Undong due to the massive influence Confucianism had on the Korean peninsula, but lacked the will to live this kind of life. They also played an important role in instilling and reinforcing a communal identity, which is essential if something akin to the Polis life and the benefits thereof, is to be enabled. In providing villagers with practical skills most were able to understand the concept of Phronesis (practical wisdom or practical philosophy). This process allowed for both character development and economic progress and through this dual process allowed for the development of a character among villagers that understood the position of the Oikos (household) and the necessity of thoughtful consideration in regard to its welfare. This consideration was due to both the micro-context of the household and also the macro-context of the village with the village chief acting as the Phronimos at a macro-context and the household head as the Phronimos in the micro-context.

Naturally, the six aforementioned concepts are based on the understanding of a character which is attuned to its emotions, one which embraces the concept of emotional intelligence(Note 4) - an idea which features strongly within Saemaul Undong doctrine and Aristotle's ethics and politics through an emphasis of our situated-ness within emotions and the impossibility of emotionless reasoning. Stated differently, it is the embracing the notion that the world is understood through emotions and that reason functions as part of and within these emotions as argued by Robert Solomon in his lecture series entitled Passions: Philosophy and the Intelligence of Emotions. An embracing of the concept of emotional intelligence implies characters which are defined by adaptability, assertiveness, low impulsiveness, self-esteem, self-motivation, social competence, effective stress management, emotion regulation, optimism, cheerfulness and satisfaction, and who are capable of communicating their feelings to others and to influence and understand the feelings of others (Furnham, 2008:57). Essentially, Saemaul Undong, like the Polis, allowed for the awakening of the understanding of individuals of their role and function within a communal context, and through this the awareness that they have, or should have, a certain kind of relationship with the 'Other' and that their being can only be satisfactory if they embrace this relationship with the 'Other'. Through this understanding the Aristotelian notion of friendship and the types of values associated with it could flourish. 
In some sense Saemaul Undong allowed for the fostering and reinforcement of a communal identity, in the sense of Aristotle's understanding of the Polis and its relation to moral and social development. This implies that the nature of humans should be understood as conforming to the notion of Homo Sociologicus(Note 5), as opposed to Homo Economicus(Note 6), which implies in a very Aristotelian sense that the being of humans can only be manifested in and through the community.

It must be noted, however, that the villages involved in Saemaul Undong differed from Aristotle's Polis in a number of ways. Firstly, there were no slaves. Secondly, women were seen as the equals of men (Lee, 1990: 5). Thirdly, the concept of Agora found within the Polis and the level of deliberation it involved as well as the contents of its deliberation differed to some extent, though not tremendously, from that found in the public sphere of villages involved in Saemaul Undong.

Naturally, it is recognised that due to relative homogeneity, something which is almost absent in SSA, Saemaul Undong might have been applied more easily to the context of South Korea, and that a lack of homogeneity might pose a major obstacle to the implementation of Saemaul Undong. However, as stated previously, Saemaul Undong might contribute significantly to identity creation, or at least allow the space for it. Saemaul Undong is, however, no quick fix solution and depends greatly on the political will and the integrity of the leadership of a state and also the true belief of participants that government has integrity, for it is only then when such a dialogue and the creation of a developmental narrative is possible.

\section{The Potential Value of Saemaul Undong as a Phronesis for the Development Malaise in sub-Saharan Africa and the Value of Aristotelian Logic to International Relations and Political Theory: South Africa as a Case Study}

It can be deduced that, by using Aristotelian logic, the potential value of the application of something akin to Saemaul Undong, as understood within the context of the Polis, should be considered by both SSA governments and donors. The emphasis on emotions, community, and the development of skills allowed for by Saemaul Undong, and hence the development of character, might allow for the transformation of feelings of hopelessness and indifference within SSA, and in so doing allow for the eradication of rural poverty. This might also lead to a greater sense of responsibility, both towards others and towards themselves, being instilled in Africans in general and African leaders, be it communal or national, specifically. (Claassen, 2011)

Saemaul Undong managed to be so successful because the emotions and attitudes of the people were understood and transformed at a grassroots level, through the direct involvement and participation of the impoverished. And, this is where the problem lies, traditionally the African National Congress (ANC) - the ruling party of South Africa since 1994 - has traditionally adopted a top down framework, with programmes such as the Reconstruction and Development Programme (RDP) and policies such as GEAR (Growth, Employment and Redistribution) due to, inter alia, lack of capacity to implement. Although one of RDP's principles is that it should be people-driven, in the sense of an active citizenry, this seems to have not been the case, likely due to the ANC's arguably majoritarian understanding of democracy. (Claassen, 2011)

Significantly, Saemaul Undong - a primarily bottom up approach - does not require the implementation capacity that RDP does, with government merely needing to supply resources and expertise, supplemented by regular inspections. Additionally, it is based on the realisation that development cannot be facilitated by simply adopting a constitution and creating new laws and by simply building houses for the populace without any real involvement of the community. By extension, it is based on the realisation that country's social ills cannot be merely drafted away by the legislature. (Claassen, 2011)

It should be realised the under apartheid the family structure of black African families was, in general, broken, and that a number of social ills stem from this. An approach hence needs to be adopted that allows for the re-construction of such family structures, through the construction of healthy and functional communities. The ANC would do well to consider the philosophy of Saemaul Undong if it desires to do so. If it truly wishes to eradicate rural poverty, it should adopt a modified Saemaul Undong-like approach which directly involves the community. The flaw that the conventional development models, as highlighted previously, contain is not only a lack of emphasis on feelings, or emotions, and attitudes, but also a lack of regard for the constructive role that something such as the notion of the Polis (or city-state, perhaps in an adapted manifestation) could play. (Claassen, 2011)

If the ANC ever wishes to eradicate racism, reduce criminal activity, combat corruption, and so on, it needs to transform the emotions of the black majority and to create healthy, functional communities and through this the re-construction of the black African family structure. If the ANC truly desires to witness the African Renaissance dreamed of by Thabo Mbeki, it should start by eradicating black African poverty, although this should not be 
taken to imply that white African poverty should be ignored. For it is only in a society where blacks and whites are equals that racism can be eliminated to some extent. The ANC needs to adopt a more pragmatic approach in other words - something more substantive - and should hence find a balance between idealistic rhetoric and pragmatism. If nothing else, at least the emphasis on emotions and attitudes that this Aristotelian reading of Saemaul Undong illustrates allows for a more nuanced understanding of the obstacles to rural development within SSA. (Claassen, 2011)

It can furthermore be deduced that the adoption of an Aristotelian-communitarian vocabulary, or at least the consideration of it (especially within international relations theory (Note 7)), could be of great value in understanding certain political phenomena. An Aristotelian vocabulary could, for instance, explain why terrorism - and other kinds of extreme behaviour - is often the result of the failure of a state, and of towns and cities within a state. This is done through an emphasis on the necessity of a properly functioning Polis if a virtuous character is to be instilled within members of a city. (Note 8) It could also lead to a better understanding of concepts such as Jus in Bello(Note 9) and the potential effects of foreign aid as well as the state's relationship $v i s-\grave{a}$-vis foreign policy within an increasingly transnational world. What should be emphasised is that good governance alone cannot lead to development, and that an active and engaged citizenry is essential if development and a healthy, functional society are to be sustained. (Claassen, 2011)

The mere imposition of liberal democracy, which typically takes a very procedural form and the adoption of liberal constitutions which follows this will not allow for much transformation within SSA. Rather, deliberation needs to be emphasised as well as grassroots movements and projects which directly involve the people. This is not to say that a form of direct democracy should be adopted, but rather that local communities, as opposed to merely capital cities, need to be emphasised in order to provide meaning to those living within those communities. (Claassen, 2011)

This vocabulary could, for instance, explain why the mere construction of RDP houses within South Africa will never be able to solve the housing crisis within the country and cure the hopelessness and indifference that plague certain impoverished South African communities. What should be learnt from the Saemaul Undong project is that government should rather act as a type of guide to community projects by providing communities with the necessary resources - such as technical expertise, training, and materials - that would allow communities to engage in a project similar to Saemaul Undong. Furthermore, by regularly investigating the progress of community projects in order to ensure that little to no corruption is occurring the community will have faith in the government, for if the community starts to doubt the integrity of government, any such project is doomed to failure. Such a process could possibly allow communities to achieve a sense of pride through the acquisition of skills and through the creation of a community that is tightly-knit and hence creates a certain sense of meaning, belonging, and responsibility for the individual within it (Note 10). This could possibly cure, to some extent, a number of problems which plague impoverished communities within South Africa and which can be linked to the nihilism connected to a loss of a sense of community, namely through alcoholism, crime and promiscuity. It has often been pointed out that one of the reasons why South Africa has experienced so many social ills is due to the breaking down of the family structure, particularly of black families, during the apartheid era. It could be suggested that it is only through such a project that former South African president Thabo Mbeki's vision of an African Renaissance can occur. (Claassen, 2011)

There are number of lessons that South Africa can learn from South Korea. Firstly, South Korea has placed a high premium on education, which has translated into a deeply entrenched culture of learning, which has been beneficial to Korean society as a whole. This culture of learning can be linked to the progressive attitude, healthy competitiveness and solidarity of South Koreans, and therefore has been imperative for the country's desire to establish a culture of excellence.

To give an example of the first point, from an early age the youth of South Korea are taught about the country's history and development. This education about the country is not only conducted in a formal manner but includes regular visits to traditional and historical sites. These field trips ensure that a culture of patriotism is entrenched amongst young people in South Korea. These excursions also create a sense of confidence about the country's progression amongst the youth. This strong belief in the development of the country is imperative in creating an engaged citizenry who are motivated to contribute to the development of South Korea - something which was highlighted in the Dinokeng Scenarios report, headed by Mamphela Ramphele, as being critical to South Africa's development. (Note 11)

Secondly, South Korea has managed to create a good balance between the modern and the traditional. South Korea's response to modernity has ensured that South Korea develops while preserving its heritage - which 
shatters the perception of a supposed dichotomy between the modern and the traditional. In other words, a developing country can integrate its traditional value system in its development paradigm.

Thirdly, the legacy of Park Chung-hee's development has evidently ensured a mostly positive inheritance that came as a result of his support of Chaebol (family-owned conglomerates) such as LG, Samsung and Hyundai which allowed for South Korea's rapid modernisation - and also his initiation of Saemaul Undong.

\section{Originarity and the Importance of Language}

Before elaborating on the relevance of the thought of Peeters on what has been discussed thus far, it would perhaps be best to first detail the key notions formulated by Peeters that will be employed within the context of this essay. Peeters (2008:28-52) formulated the notion of Originarity (Note 12) with the intention of overcoming the structuralist or poststructuralist understanding of language as something that is merely a medium of communication (Mühr, 2009:221). This endeavour was motivated by the conviction held by Peeters that the structuralist movements of the $20^{\text {th }}$ century obscured certain understandings of the role of language (Mühr, 2009:221). Peeters formulated the term Originarity in order to highlight the 'essence by which something comes into existence' (Mühr, 2009:221) and as a way to explain 'the emergent potentials of language and its ontological human status' (Mühr, 2009:221). For Peeters language is both a phenomenon and an ability or potential that humans possess (Mühr, 2009:221). Furthermore, in comparing the abstract notion of 'language' to the concrete notion of 'speech', Peeters holds that if language is seen as 'speech' and its meaning is understood to conform to the notion of Originarity, it can be argued that 'speech is clearly a phenomenon by which at least two people meet and experience themselves in an interpersonal, dialogical togetherness' (Mühr, 2009:221). Peeters even goes on to argue that 'even in monological, written speech, an interpersonal relation must at least be hypothesized in order to make sense, because language is inter-subjective' (Mühr, 2009:221). Peeters essentially holds that 'humans have to externalize their existence by means of language; we have to speak in order to be able to experience ourselves as being(s) in the world' (Mühr, 2009:222). Peeters thus views authentic language as something that is Originative and that through being actants - by speaking in fact since it reverberates and can effect changes in the speaker himself or herself - humans can discover who they are and also who they are making themselves out to be. Thus, experience can either augment or damage a person - if he lies or just uses readymade expressions and platitudes -since experience brings a person's sense of existence to issue.

It can be added that recognition is thus integral to the notion of language, and language itself can be understood as a struggle for recognition. Language manifests our desire for recognition. (Note 13) It should be added that this is only true provided we recognize the 'Other', this recognition should be reciprocal otherwise we fall in Hegel's master-servant trap. Understanding and existential communication must be mutual so that we both become more ourselves through the other.

Life is a narrative. Through language humans can create, alter or maintain a certain narrative - a lived narrative in the sense of a narrative identity. A narrative since it has beginning, incidents, and an end gives direction and sense to what happens to us and fortifies our own identity inside the community. In this sense dialogue provides humans with a narrative. Dialogue would be the way in which our 'narrative' is shared and touches also the other so that both of us change: the relation is triangular. Each of us is I/You and he/she and through this dynamic triad we become ourselves.

\subsection{Communitarianism versus Cosmopolitanism/Liberalism}

It can be argued that in adhering to the ideas mentioned in the previous section that an argument for a communitarian understanding of our being - as encapsulated by the notion of Homo Sociologicus - is being presented, as opposed to one that would favour cosmopolitanism and liberalism - both notions based on the notion of Homo Economicus. The aforementioned essentially emphasises the value of community and our being within a community. We can only express and experience our being through community. However, this should not be taken to imply that any type of community allows for this experience and expression, in a relativist sense. Totalitarian regimes such as North Korea, which is a Stalinist dictatorship centred on the notion of Juche (Note 14), create a climate of fear which certainly does not allow for the experience and expression of the self. Rather, the type of community that allows for individuality within the context of a community, as encapsulated by the notion of deliberative democracy (Note 15) and opposed to a merely procedural liberal democracy, is the type of community which should be sought. However, the point remains that the individual can no longer be viewed in total isolation from society, and this necessitates a radical alteration of our understanding of society and its laws. For instance, rights should be understood as something which also encapsulates certain responsibilities. Only such a radical shift can allow for diseases such as depression, loneliness, apathy, degeneration, emptiness, sense of meaninglessness, et cetera - all of which plague modern globalised metropolises - to be addressed. 


\subsection{Bernard Stiegler's notion of de-individuation}

For Stiegler (2009:39-41), this de-individuation ultimately leads to, among other things, loneliness, boredom, and idiocy. Stiegler holds that the aforementioned are symptoms of the loss of primordial narcissism. To elaborate, for Stiegler the destruction of individuation correlates with the destruction of the capacity - both individually and collectively - for self-love. Stiegler holds that narcissism is not merely a symptom of the egotism associated with consumption capitalism, but, more fundamentally, it is the necessity for the $I$ and the $W e$ to possess a sense of existence, of being individual, of mattering. Narcissism is thus a positive sense of individuation, an $I$ that is a $W e$. The loss of individual and collective narcissism associated with consumption capitalism - and the loss of a sense and a love of self which accompanies it - inevitably leads to transgressions, to acts of violence where individuals, or collectives, desperately seek to re-discover - or even assert - their existence, both individually and collectively. (Stiegler, 2009: 39-41)

Essentially, in the modern globalising world our techno-existence is increasingly creating an existence where communication - language as a means - is abundant but where we are struggling to assert our existence through language, due to a great homogenisation process. Our vocabulary is becoming increasingly homogenised. Conformity has become king. This is possible because all communication is ultimately founded in 'existential communication', humans being themselves 'trans' through the other since they all are 'in' Life which is the encompassing realm in which care and responsibility can deploy themselves.

It is only in the type of community where substantive deliberation is valued, such as in ancient Athens and in the notion of a deliberative democracy, that the aforementioned diseases can be addressed, to some extent.

The modern homogenising process does not value uniqueness, and hence desires to see humans conform to a certain understanding of what a human being should be. Rather, an alternative should be sought. Aristotle's notion of the Polis and the role it plays in allowing humans to achieve Eudaimonia should be seen as a possible alternative since it does not prescribe an exact model of the ideal human in the sense of ideas that the model human should maintain, as encouraged by ideas such as political correctness. Rather, this notion encourages the development of certain values which can act as a compass to thinking, but which is not totally prescriptive in the sense of dictating how these values should be expressed and interpreted, and which ideas should be attached to these values - a character is encouraged which can act as a foundation from which personal exploration can occur. In this sense it allows for room for interpretation and personal expression, and hence for the manifestation of our own being. In this sense there are similarities with Rorty's notion of the liberal ironist (Note 16) and liberal utopia.

It should be realised - if dialogue is to be embraced - that there are no simple recipes, no simple answers and that this need for simple answers and simple recipes - a pathology that plagues the modern mind - should be abandoned. Conformity, and consensus by extension, is not something to be celebrated. Dialogue should be constant. The beauty in life - and its meaning - lies in its complexity and openness. Space is always open for exploration, and hence assertion of our being through dialogue. Although blindly adopting character-based approaches would also lead to falling within the same trap, it should be pointed out that character-based approaches - such as Aristotle's virtue ethics - allows for some degree of flexibility as it is not as prescriptive as action and rule-based approaches, such as consequentialism, deontological ethics, religious fundamentalist approaches, et cetera.

In such a context dialogue can be meaningful and experience can truly alter our being. In a homogenising process, experience becomes meaningless. This necessarily creates tension and leads to deviant types of behaviour as the self attempts to manifest itself. Dialogue - and philosophy - needs to alter our being. Words are meaningless if they have no substantive effect on our understanding of ourselves, if they do not challenge us. This lack of challenge leads to a lack of feeling of existence. It depresses our desire for recognition. Totalitarian and modern globalising societies do not allow for this dialogue with both us and others - and hence not for self-recognition and recognition by others - and this is leading to deviant forms of behaviour.

The effects of the lack of this recognition due to a lack of dialogue can be witnessed in South Africa, with it being possible to argue that one of the reasons why crime is so violent in South Africa is due to a lack of recognition of and from other ethnic groups within South Africa. It could be possible that criminals are attempting to express their being, especially through crimes like rape. This sense of emptiness possibly leads to these types of crimes. (Claassen, 2011)

Importantly, and almost as a concluding note, if the ANC ever wishes to facilitate an African Renaissance it should revitalise the use of indigenous South African languages within communities. It should be noted that this does not mean that English should be discarded as the lingua franca within South Africa. African languages are 
an important component to any such transformation since, firstly, a type of dialogue is required between those participating and the state, and, secondly, because an African Renaissance should, normatively speaking, occur within the framework - or Weltanschauung - of African languages if it is to be truly African. A type of pride should be instilled within African communities in order for such a project to be successful, and merely adopting English and looking towards African-Americans as role-models will not allow for any such revolution to occur. It is only when such a pride is re-instilled that success can follow, even within the field of sport. (Claassen, 2011)

It should be noted that what is being proposed is a type of radical communitarianism with an Aristotelian departure point - and hence an Aristotelian vocabulary - and not communism. A type of communitarianism which is liberal and understands the individual as an individual within a community, as opposed to an individual isolated, and an individual with a responsibility towards both him/herself and the community is being proposed. It is only when the recognition which accompanies responsibility is achieved that crime and racism may be combated - for example, crimes such as rape, and extremely violent crime in general (Note 17) (Note 18) which sometimes stem from the desire for recognition from either another ethnic group or even members of the same ethnic group, or even society as a whole. When the individual is understood as an individual within a community that desires a sense of belonging (which allows for the creation of a sense of responsibility) and something from which meaning can be derived, it allows for the creation of a conceptual framework which can, to some extent, explain responsible and irresponsible behaviour by emphasising the role of the community. (Claassen, 2011)

To reiterate a point made earlier, one of the reasons why so much irresponsible behaviour is witnessed in South Africa is possibly due to the breakdown of the black African family. It is recognised that for this type of radical communitarianism to function properly it should function within the context of the liberal tradition (which emphasises the importance of embracing modernity) which allows for deliberation, and hence dialogue and the creation of certain narratives and narrative identities, or even the creation of the liberal ironist, as described by Rorty. Of course, for any such dialogue to be effective, sincerity is required. (Claassen, 2011)

\subsection{South Korean Cinema and Society}

South Korea has to some extent been protected from the pernicious effects of the processes described earlier due to its strongly embedded communitarian tradition. This is not to say that South Korea is entirely conformist (Note 19). However, it is evident that the seeds of dialogue have been planted, as manifested in South Korean cinema. For instance, a shift has contemporaneously been witnessed in the South Korean family structure from a patriarchy - as it was in the 1950s - to a matriarchy, with women coming to play an increasingly prominent role in society and feminism becoming increasingly entrenched within the Weltanschauung of South Koreans. Although South Korea has gained prominence for the Miracle on the Han River, it should not be forgotten that South Korea has also rapidly developed in terms of the social and political. This has been reflected within South Korean cinema, with cinema often acting as the instigator of such transformation. It must be added that the majority of Hollywood films do not attempt to challenge the Weltanschauung of those watching it, but rather just act as an exercise in conformity.

In recent South Korean cinematic history, titles such as My Wife Got Married (2008) (Anaega gyeolhonhaetda/아내가 결혼했다), 3-Iron (2004) (Bin-jip/빈집), and Spring, Summer, Fall, Winter... and Spring (2003) (Bom yeoreum gaeul gyeoul geurigo bom/봄, 여름, 가을, 겨울 그리고 봄) have served to challenge the South Korean Weltanschauung and to encourage dialogue between and within Koreans, South Korea, and foreign cultures, as can be seen by its partial embracing of Western culture (Note 20) (Note 21). This has necessarily opened South Koreans up to inter-cultural dialogue. This has allowed for the rapid social transformation and development of South Korea - with the understanding that development is not linear, but rather that it is open-ended in a non-relativist way through the interpretation of certain values. Notably, this trend started in the 1950s. This radical change and constant questioning of existing family structures is remarkable given that South Korea was, until the $20^{\text {th }}$ century, the country with the strongest neo-Confucian tradition in the world.

This questioning of the family structure is not isolated. Dialogue is raging over numerous aspects of society. This has led to South Korea becoming one of the world's 28 full democracies, which is remarkable given that South Korea was authoritarian in the 1970s. To put into context this rapid social change, South Africa, Brazil, and Poland are all ranked as flawed democracies.

\section{Conclusion}

South Korea's rapid economic and social development can be said to be a result of openness to dialogue (and hence new experiences), as manifested both in Saemaul Undong and South Korean cinema. This has allowed for 
a temporary escape from the nihilism that plagues many Western and African societies, where the notion of the community - and hence meaningful dialogue - has largely been discarded and has allowed for self-assertion.

SSA could greatly benefit if it looks to South Korea and employs the Aristotelian-communitarian vocabulary, or some variant of it, outlined in this paper. This kind of logic would certainly allow it to pass some Weltanschauung impasses.

Importantly, it should be noted that this paper does not argue that modernity - and postmodern philosophy by extension - should be discarded, but rather that a type of character turn is needed in the sense of a re-embracing of Aristotle through the adoption of an Aristotelian-communitarian vocabulary (Note 22).

\section{References}

Agbese, P.A. \& Kieh, G.K. (2007). Introduction. Reconstituting the State in Africa. Basingstoke: Palgrave Macmillan.

Boekle, H. Rittberger, V. \& Wagner, W. (2001). Constructivist foreign policy theory. In Rittberger V (ed.), German foreign policy since unification: theories and case studies. Manchester: Manchester University Press.

Claassen, C.H. (2011). Addressing Black African Poverty in South Africa. Young Academic. [Online] Available: http://www.youngacademic.co.uk/category/opinion.

Douglass, M. (1983). The Korean Saemaul Undong: accelerated rural development in an open economy. In Lea, A.M. \& Chaudhri, D.P. (Eds), Rural Development and the State: Contradictions and Dilemmas in Developing Countries. New York: Methuen \& Co.

Dupre, B. (2007). Virtue Ethics. In 50 Philosophy Ideas You Really Need to Know. London: Quercus Publishing.

Furnham, A. (2008). 50 Psychology Ideas You Really Need to Know. London: Quercus Publishing.

Ho, S.P.S. (1979). Rural-Urban Imbalance in South Korea in the 1970s. Asian Survey, 19(7).

Knight, J. (1994). Rural Revitalization in Japan: Spirit of the Village and Taste of the Country. Asian Survey, 34(7).

Lee, M.S. (1990). Policy and Rule Configuration: Korean Rural Development Movement Saemaul Undong. Workshop in Political Theory and Policy Analysis, Indiana University, 28-30 April 1990.

Lockwood, M. (2005). States of Development, Prospect. [Online] Available: http://www.energie-omd.org/guidepratique/IMG/pdf/Prospect_-_States_of_Development.pdf.

Mühr, S. (2009). Authenticity and originarity in foreign language learning in the diaspora. Stellenbosch Paper in Linguistics PLUS, 38.

National Council of Saemaul Undong Movement in Korea. (1999). Saemaul Undong in Korea. [Online] Available: http://www.saemaul.or.kr/english/.

Oakeshott, M. (2006). Lectures in the History of Political Thought. In Nardin, T. \& O'Sullivan, L. (Eds). Exeter: Imprint Academic.

Park, S.Y. (2009). Analysis of Saemaul Undong: A Korean Rural Development Programme in the 1970s. Asia-Pacific Development Journal, 16(2).

Peeters, L. (2008). Taalvermoë en originariteit. Acta Academica, 40(2).

Rodrik, D. (1996). Understanding Economic Policy Reform. Journal of Economic Literature, 34(1).

Sang-Mok Seo. (1981). Definition of poverty and time series analysis. [Online] Available: http://www.kdi.re.kr/kdi/report_read05.jsp?pub_no=00003580 (March 21, 2008).

Soon-Wan Kwon. (1997). Korean experience in poverty alleviation with specific reference to Saemual Undong. Social Security Review, 13(1).

Stiegler, B. (2009). Acting Out. Stanford: Stanford University Press.

\section{Notes}

Note 1. Translated as the 'New Community Movement'.

Note 2 . The 16 highest priority projects were, (1) village access roads to be straightened and widened, (2) old bridges over streams to be reconstructed, (3) village roads to be widened and straightened, (4) sewage systems in village area to be improved, (5) thatched roofs to be replaced by cement tiles, (6) old fences of farm houses to be repaired, (7) traditional wells for drinking water to be improved, (8) village hall to be constructed, (9) banks of 
brooks to be repaired, (10) feeder roads to fields to be developed, (11) rural electrification to be speeded up, (12) village owned telephones installed, (13) village owned bathhouse to be built, (14) children's playground to be constructed, (15) washing places in riverside to be improved, (16) planting of trees and flowers for beautification.

Note 3. See Park (2009:120). Table 5 acts as an indicator of a success of the mentioned projects

[approximate location of Table 5]

Note 4. It should be noted that although the concept of 'social intelligence' was only introduced in 1920 (and even though Daniel Goleman published the first real popular book on the topic, entitled Emotional Intelligence, Aristotle's ethics and politics, combined, seem to emphasize emotional intelligence even though Aristotle himself would probably not have used the term. See Furnham (2008:56-57).

Note 5. Or 'social man', a concept based on the notion of the behaviour - the interests, codes of conduct, et cetera - of humans being defined by society. Humans are thus viewed as being part of a society or community, which implies a disposition towards legality, humaneness, and responsibility. See Boekle, Rittberger and Wagner (2001: 106-107).

Note 6. Or 'economic man' - a concept based on the notion of humans adhering to rational choice theory, consequentialist reasoning and being broadly self-interested and viewing themselves individually. See Boekle et al (2001:106-107).

Note 7. Books such as International Relations Theories: Discipline and Diversity (2007), Theories of International Relations (2009), The Globalization of World Politics: An Introduction to International Relations (2008), International Relations Theory Today (1995), and International Relations Theory; Realism, Pluralism, Globalism, and Beyond (1999), are all dominated by cosmopolitan and communitarian ethics. Although Aristotle can be said to belong to the communitarian tradition, within the field of international relations theory an Aristotelian vocabulary can be adopted to understand certain concepts in a non-communitarian manner.

Note 8 . It is noted here that the Polis should be equated to the city-state, not a state. The point made is that the failure of numerous cities and villages would necessarily have an impact on people, and be reflected, at a state level.

Note 9. Although Aristotle's never discussed Jus in Bello, an Aristotelian vocabulary can certainly be applied to the concept, very much like Thomas Aquinas employed an Aristotelian vocabulary in order to better understand and explain certain phenomena. See Oakeshott (2006:341).

Note 10. This is an approach which necessarily advocates a holistic understanding of humans and hence advocates a type of holistic education.

Note 11. As observed by a colleague - Khwezi Mabasa - and I during a trip to South Korea sponsored by the NIIED (National Institute for International Education Development) of South Korea in 2010.

Note 12. Originariteit in Afrikaans, as found in Peeters (2008:28-52).

Note 13. Or Thymos - an ancient Greek word which can be translated as 'spiritedness'; the word essentially expresses the human desire for recognition and was popularized by Francis Fukuyama, as inspired by a Kojève's reading of Hegel, when he so famously expressed it in The End of History and the Last Man (1992) as the motor of human sociocultural and political evolution, which would culminate in liberal democracy.

Note 14. This can be described as a notion which emphasizes self-reliance and extensively draws from the ideology of National Socialism.

Note 15. A democracy that is something more substantive.

Note 16. A being who embraces modernity in the sense of embracing liberal values, but who is also creative, or poetic, in the, inter alia, Nietzschean and Heideggerian sense where identity is to a large extent informed by creativity. This notion is based on the realization that life is like a story - a narrative - and that each chooses his or her own narrative to embrace, even religious fundamentalists. Though, a religious fundamentalist would certainly not be classified as being a liberal ironist.

Note 17. The violence which accompanies crime in South Africa has distressed many within South Africa.

Note 18. It is important to recognize the detrimental effect that the breakdown of the traditional family structure and communities during Apartheid has had. This breakdown may have led to, inter alia, the proliferation of feelings of hopelessness, indifference, isolation, and abandonment and, as a related point, also to the failure to nurture both a sense of responsibility towards both oneself and others. The desire for recognition - from other ethnic groups and one's own ethnic group, or community, and society as a whole - of many might hence have 
not been fulfilled and this might be one of the reasons why rape is so common and why it is at times so violent. Unemployment, poverty, and inequality have only aided the proliferation of such feelings and the failure to develop a sense of responsibility and a sense of community. Hence, due to the breakdown of the family and the community vices such as greed, lack of communal and social responsibility, and indifference to the feelings of others, have become embedded in the world view of many.

Note 19. Although, some kind of conformity is necessary if dialogue is to take place, as illustrated by Rorty's notion of the liberal utopia.

Note 20. This has happened to some extent. It has, however, led to some kind of fusion within which dialogue has been raging.

Note 21. See Kang, S.R. (2009) Changes in the Korean Family as Seen in the Movies. [Online] http://www.koreafocus.or.kr/design2/layout/content_print.asp?group_id=102556. Kang (2009) is essentially an illustration of this idea.

Note 22. It is understood that no vocabulary can ever be the final, or ultimate, vocabulary, but rather that certain vocabularies need to be adopted in response to certain problems or issues in a linearly-progressive Hegelian-like form, with Thymos being the motor of development. Thus, the most any vocabulary can hope for is influence. Some Eastern thinkers may argue that history and all social phenomena are either (a) circular or (b) like a pendulum; however such a framework of understanding does not help in understanding the project being investigated within this paper.

Table 1. Change in the poverty rate and the number of people living in poverty

(Thousands of people, percentage)

\begin{tabular}{|c|c|c|c|c|c|c|c|c|c|}
\hline & \multicolumn{3}{|c|}{1965} & \multicolumn{3}{|c|}{1970} & \multicolumn{3}{|c|}{1978} \\
\hline & Urban & Rural & Total & Urban & Rural & Total & Urban & Rural & Total \\
\hline $\begin{array}{l}\text { Number of } \\
\text { people in } \\
\text { absolute } \\
\text { poverty } \\
\text { (thousands) }\end{array}$ & 4244 & 7505 & 11749 & 2006 & 5548 & 7554 & 2552 & 1995 & 4547 \\
\hline $\begin{array}{l}\text { Distribution } \\
\text { of people } \\
\text { in absolute } \\
\text { poverty } \\
\text { (percentage) }\end{array}$ & 36.1 & 63.9 & 100.0 & 26.6 & 73.4 & 100.0 & 56.1 & 43.9 & 100.0 \\
\hline $\begin{array}{l}\text { Absolute } \\
\text { poverty rate }\end{array}$ & 54.9 & 35.8 & 40.9 & 16.2 & 27.9 & 23.4 & 13.75 & 10.80 & 12.28 \\
\hline $\begin{array}{l}\text { Relative } \\
\text { poverty rate } \\
\text { (percentage) }\end{array}$ & 17.9 & 10.0 & 12.2 & 7.0 & 3.4 & 4.8 & 16.6 & 11.2 & 13.9 \\
\hline
\end{tabular}

Source: Data based on Sang-Mok Seo (1981). "Definition of poverty and time series analysis", accessed from www.kdi.re.kr/kdi/report/report_read05.jsp?pub_no=00003580 on March 212008.

Note: In this study, absolute poverty is defined as a monthly household income which is below W20,000 for an urban household and W17,000 for a rural household. Relative poverty is defined as a household income lower than one third of the average national household income level (all incomes are estimated in 1980 Korean won). 
Table 2. Ratio of rural household income to urban household income

(Unit: Korean won)

\begin{tabular}{|cccc|}
\hline Year & $\begin{array}{c}\text { Average monthly income } \\
\text { of urban household }(A)\end{array}$ & $\begin{array}{c}\text { Average monthly income } \\
\text { of rural household }(B)\end{array}$ & $\begin{array}{c}\text { Ratio } \\
(B) /(A) \text { (percentage) }\end{array}$ \\
\hline 1967 & 20720 & 12456 & 60.1 \\
1970 & 31770 & 21317 & 67.1 \\
1973 & 45850 & 40059 & 87.4 \\
1976 & 95980 & 96355 & 100.4 \\
1979 & 219133 & 185624 & 84.7 \\
\hline
\end{tabular}

Source: Soon-Won Kwon (1997). "Korean experience in poverty alleviation with special reference to the Saemaul Undong", Social Security Review, vol. 13, No. 1, June (Korean Social Security Association), p. 194.

Table 3. Farming thousehold income in the 1970s

(Unit: Korean won)

\begin{tabular}{|cccccc|}
\hline Year & $\begin{array}{c}\text { Household } \\
\text { income }\end{array}$ & \multicolumn{2}{c|}{ Agricultural income } & \multicolumn{2}{c|}{ Non-agricultural income } \\
\cline { 2 - 6 } & Amount & Amount & $\begin{array}{c}\text { Ratio } \\
\text { (percentage) }\end{array}$ & Amount & $\begin{array}{c}\text { Ratio } \\
\text { (percentage) }\end{array}$ \\
\hline 1970 & 255800 & 194000 & 75.9 & 61800 & 24.1 \\
1973 & 480700 & 390300 & 81.2 & 90400 & 18.8 \\
1976 & 1156300 & 921200 & 79.7 & 235100 & 20.3 \\
1979 & 1531300 & 1531000 & 68.7 & 696200 & 31.3 \\
\hline
\end{tabular}

Source: National Council of Saemaul Undong Movement in Korea (1999) "Saemaul Undong in Korea", p. 38, accessed from www.saemaul.com/center/www/caups/down/issue/새마을운동(영문).pdf on 25 March 2008.

Table 4. Comparison of per capita rural income to urban income

(Unit: thousands of Korean won)

\begin{tabular}{|cccccccc|}
\hline \multirow{2}{*}{ Year } & \multicolumn{2}{c}{ Urban household } & \multicolumn{2}{c|}{ Rural household } & \multicolumn{2}{c|}{ Ratio } \\
\cline { 2 - 7 } & $\begin{array}{c}\text { Per capita } \\
\text { income }(A)\end{array}$ & $\begin{array}{c}\text { Per capita } \\
\text { working } \\
\text { income }(B)\end{array}$ & $\begin{array}{c}\text { Per capita } \\
\text { income (C) }\end{array}$ & $\begin{array}{c}\text { Per capita } \\
\text { agricultural } \\
\text { income }(D)\end{array}$ & $(C / A)$ & $(D / B)$ \\
\hline 1963 & 12 & 60 & 15 & 24 & 1.22 & 0.40 \\
1965 & 16 & 92 & 18 & 28 & 1.09 & 0.31 \\
1970 & 55 & 254 & 43 & 67 & 0.79 & 0.26 \\
1975 & 140 & 538 & 155 & 250 & 1.11 & 0.43 \\
1980 & 558 & 2144 & 527 & 705 & 0.94 & 0.33 \\
1985 & 1087 & 3912 & 1220 & 1492 & 1.12 & 0.38 \\
\hline
\end{tabular}


Table 5. Major achievements of some Saemaul Undong projects in the 1970s

\begin{tabular}{|c|c|c|c|c|}
\hline Project & Unit & Target & Performance & $\begin{array}{c}\text { Ratio } \\
\text { (percentage) }\end{array}$ \\
\hline Village roads expansion & $\mathrm{Km}$ & 26266 & 43558 & 166 \\
\hline Farm feeder roads construction & $\mathrm{Km}$ & 49167 & 61797 & 126 \\
\hline Small bridge construction & Ea & 76749 & 79516 & 104 \\
\hline Small reservoirs construction & Ea & 10122 & 10742 & 106 \\
\hline Traditional small irrigation (channel) & Ea & 22787 & 28352 & 124 \\
\hline Traditional small irrigation (raceway) & $\mathrm{Km}$ & 4043 & 4442 & 109 \\
\hline Traditional small irrigation (embankment) & $\mathrm{Km}$ & 17239 & 9180 & 53 \\
\hline Village centre construction & Ea & 35608 & 37012 & 104 \\
\hline Public warehouse construction & Ea & 34665 & 22143 & 64 \\
\hline Housing improvement & Ea & 544000 & 225000 & 42 \\
\hline Village layout renovation & Ea & - & 2747 & - \\
\hline Sewage system upgrade/construction & $\mathrm{Km}$ & 8654 & 15559 & 179 \\
\hline Electricity supply system installation & Household & 2834000 & 2777500 & 98 \\
\hline Telephone lines & & - & 345240 & \\
\hline Saemaul factory construction/operation & Ea & 950 & 717 & 75 \\
\hline Reforestation & Ha & 744354 & 347153 & 47 \\
\hline
\end{tabular}

